\title{
SANKSI PIDANA TERHADAP TINDAK PIDANA KORUPSI DANA HIBAH
}

\author{
I Wayan Agus Yudana, INyoman Sujana, A.A.SagungLaksmiDewi \\ Fakultas Hukum Universitas Warmadewa, Denpasar - Bali, Indonesia
}

\begin{abstract}
Abstrak
Korupsi dana subsidi adalah hal biasa di masyarakat dan sering terdengar melalui media dan berita di berbagai tempat. Hibah ini sering menimbulkan berbagai masalah, khususnya yang timbul dari Anggaran Pendapatan dan Belanja Daerah (APBD), baik selama pelaksanaan maupun pengelolaan atau pembayaran. Ada banyak penyalahgunaan dana subsidi untuk keuntungan pribadi. Sesuai dengan latar belakang dimaksud, penelitian ini fokus pada penguraian pengaturan tentang tindak pidana korupsi dana hibah dan pendeskripsian sanksi pidana terhadap pelaku yang melakukan tindak pidana korupsi dana hibah. Penelitian ini didesain dengan menggunakan tipe penelitian normatif dan datanya bersumber pada studi pustaka dan hukum positif yang berlaku. Pada perkara Nomor : 32/Pid.Sus.TPK/2016/PN.Dps terdakwa dengan inisial IWB sudah secara nyata melakukan korupsi pada dana hibah sesuai perundangan berlaku, untuk selanjutnya Majelis Hakim menghukum dengan pidana kurungan satu tahun dan bayar ganti rugi lima puluh juta rupiah. Seandainya tidak membayar denda itu, digantikan dengan penjara 1 bulan dan ia harus mengembalikan uang negara senilai tiga ratus lima puluh juta rupiah. Setelah dilakukan analisis, maka dapat disimpulkan bahwa sesuai ketentuan Pasal 2 dan Pasal 3 UU 20 Tahun 2001, maka hukuman penjara dapat dikenakan pada pelaku tindak pidana korupsi dana hibah.
\end{abstract}

Kata Kunci: Dana Hibah; Pengaturan; Tindak Pidana Korupsi

\begin{abstract}
Corruption of subsidy funds is common in the community and is often heard through the media and news in various places. These grants often cause various problems, especially those arising from the Regional Budget (APBD), both during implementation and management or payment. There is a lot of abuse of subsidized funds for personal gain. In accordance with the background description, this research focused on the elaboration of the regulation regarding the criminal act of corruption of grant funds and the description of criminal sanctions against perpetrators who commit criminal acts of corruption of grant funds. This study was designed using a type of normative research, and the data was collected from literature studies and positive laws that apply. In case Number: 32 / Pid.Sus.TPK/2016 / PN.Dps the defendant with the initials IWB had actually committed corruption in the grant funds according to the law in force, henceforth the Panel of Judges sentenced them to one year imprisonment and paid compensation fifty million rupiah. If he did not pay the fine, it would be replaced with a 1-month prison term and he would have to return the state money worth three hundred and fifty million rupiah. After the analysis was done, it can be concluded that according to the provisions of Article 2 and Article 3 of Law 20 of 2001, the prison sentence may be imposed on the perpetrators of the crime of grant funding.
\end{abstract}

Keywords: Corruption; Regulation; Grant Funds

\section{PENDAHULUAN}

Korupsi adalah momok bagi setiap negara di dunia. Korupsi yang sangat kuat akan memiliki konsekuensi dari pembangunan yang terhambat di suatu negara (Cohan, 2000). Kesan pemerintah menjadi buruk karena korupsi tidak dapat diberantas. Implikasinya ketidakpercayan publik muncul pada pejabat dan kurang patuh pada keberlakuan hukum, sehingga masyarakat miskin pun terus menjulang tinggi (Djelantik, 2008). Korupsi adalah masalah yang saat ini dirasakan lebih cepat seiring dengan semakin berkembangnya bangsa yang maju. Meningkatnya kebutuhan juga mendorong mendorong seseorang untuk melakukan tindak pidana korupsi (Hamzah, 2005). Korupsi mendapatkan perhatian lebih banyak bila dibanding masalah lain di seluruh permukaan bumi. 
Korupsi adalah tindakan melawan hukum dengan memperkaya diri sendiri atau orang lain (Zulkifli, Fitriati, \& Ferdi, 2018). Memahami korupsi, baik dalam arti hukum dan dalam arti umum, sebenarnya sama. Ini berarti merujuk secara hukum pada unsur-unsur pelanggaran sebagaimana dirumuskan dalam undang-undang, sementara korupsi umumnya ditafsirkan lebih sebagai tindakan suap, penyalahgunaan wewenang atau melawan hukum yang merusak diri sendiri, pengaruh perdagangan yang tercela di alam. Menurut Fockema Andreae, kata korupsi dari korupsi atau korupsi Latin dimulai corruptio kata dasarnya corrumpere, sebutan Latin yaitu yang lebih tua. Bersumber dari bahasa Latin datang ke bahasa Eropa antara lain Inggris, yaitu korupsi, Perancis adalah korupsi dan Belanda korupsi. Kata itu berasal dari bahasa Indonesia, yaitu korupsi. Kita harus menyadari bahwa peningkatan tindak pidana korupsi yang tidak terkendali tidak hanya akan memiliki konsekuensi pada hilangnya negara dan ekonomi nasional, tetapi juga pada kehidupan bangsa dan negara.

Korupsi menjadi kejahatan luar biasa karena melanggar hak sosial ekonomi masyarakat, bukan lagi termasuk kejahatan biasa (Djaja, 2010). Semua bidang kehidupan akan terkena imbas korupsi. Korupsi bisa membuat negara menjadi labil dan tidak aman, pembangunan sosial ekonomi dan politik pun ikut terancam, nilai demokrasi dan moralitas turut tercoreng (Poveda, Carvajal, \& Pulido, 2019). Perlahan perubahan ini akan membudaya di masyarakat. Cita-cita mewujudkan masyarakat adil makmur menjadi terancam.

Sejauh ini, korupsi telah ditoleransi oleh pihak tertentu daripada diberantas, sementara korupsi adalah perbuatan jahat yang memiliki pengaruh pada kepentingan berbeda terkait dengan hak asasi manusia, ideologi, ekonomi dan finansial, sehingga moral nasional sulit diatasi. Kesulitan dalam mengatasi korupsi atau mengurangi korupsi dapat dapat dilihat dari pembebasan bebas tersangka dalam kasus korupsi atau sedikitnya hukuman yang dijatuhkan kepada tersangka dalam kasus korupsi yang tidak sebanding dengan apa yang dia lakukan. Ini sangat berbahaya bagi keuangan negara dan menghambat pembangunan nasional. Jikalau ini terjadi dalam waktu yang berulang-ulang, itu bisa berimbas pada berkurangnya rasa adil dan percaya diri pada aturan oleh warga negara (Riawati, 2016).

Belakangan ini, kasus korupsi dalam dana bersubsidi berlangsung di masyarakat dan terdengar lewat media dan informasi di semua lokasi. Hibah adalah jenis pengeluaran daerah yang menarik perhatian banyak pihak, tidak hanya masyarakat atau kelompok masyarakat, tetapi juga pemerintah, anggota dewan legislatif daerah, bupati, gubernur, walikota yang memiliki minat dalam dana hibah, sehingga dana yang disumbangkan memiliki risiko cukup tinggi untuk disalahgunakan atau dianiaya.

Ada sejumlah masalah yang berkaitan dengan dana hibah, termasuk ketentuan dana hibah yang tidak mematuhi persyaratan atau prosedur pembayaran, bantuan hibah tidak diterima atau diterima oleh beberapa pemegang hak sebagaimana dinyatakan dalam proposal yang sengaja dibuat fiktif. Dalam praktiknya selama ini, dana hibah ini sering menimbulkan berbagai masalah, khususnya yang timbul dari Anggaran Pendapatan dan Belanja Daerah (APBD), baik selama pelaksanaan maupun pengelolaan atau pencairan (Arifin \& Yusnita, 2017). Ada banyak penyalahgunaan dana subsidi untuk keuntungan pribadi. Urusan pemerintah daerah didukung dengan adanya hibah sebagai konsep pemberian hibah oleh pemerintah. Tujuan program dan aktivitas pemerintah dapat terwujud sembari prinsip adil, sopan, rasional dan manfaat bagi masyarakat bisa dihormati yang selaras dengan prinsip tata kelola keuangan daerah.

Dalam beberapa kasus, dana yang digunakan untuk hibah tidak sejalan dengan proposal yang diajukan, biasanya digunakan secara pribadi untuk memperkaya diri (Pradana, 2020). Selain itu, akuntabilitas untuk pengeluaran biasanya tidak didukung oleh bukti lengkap dan waktu pengiriman lebih lama karena SPJ fiksi yang memakan waktu.

Korupsi benar-benar busuk, jahat, dan merusak (Widiastuti, 2009). Berkenaan dengan berbagai bentuk korupsi yang telah terjadi di Indonesia, misalnya: korupsi dalam pembelian barang dan paket, penggelapan, peningkatan anggaran, penyalahgunaan anggaran, dan subsidi serta bantuan sosial. Korupsi dana subsidi memunculkan sejumlah aktor penting korupsi, antara lain kepala daerah, pemegang jabatan lingkungan pemerintah daerah, serta staf dan atasan legislatif daerah (Setiyono, 2017).

Berdasar permendagri tentang pedoman untuk manajemen keuangan daerah, pengeluaran subsidi adalah selektif dengan mempertimbangkan kapasitas keuangan daerah, rasionalitas dan ditentukan oleh keputusan daerah. Dengan pemberlakuan peraturan menteri, kemudian terdapat penyempurnaannya, maka subsidi menjadi semakin selektif dan lebih ketat sejak tahun fiskal 2012. Kriteria seperti 
pembatasan pemberian subsidi, pengajuan proposal bagi subsidi, penetapan anggaran, pewujudan dan penyalurannya sampai dapat mengantisipasi penyimpangan dalam mekanisme subsidi dari proses pengajuan proposal atau aplikasi untuk subsidi, penganggaran oleh pemerintah daerah, pembentukan dan distribusi dana subsidi, sampai akuntabilitas dan pemantauan serta evaluasi pembiayaan hibah, diperlukan oleh Kementerian Dalam Negeri agar mekanisme subsidi melalui tahapannya bisa diantisipasi.

Ekonomi negara yaitu kehidupan perekonomian yang dirancang sebagai usaha bersama berasas kekeluargaan/usaha kemasyarakatan yang individual berdasar kebijaksanaan pemerintah di pusat ataupun daerah menurut berlakunya perundangan, tujuannya agar bermanfaat, sehingga hidup rakyat menjadi makmur dan sejahtera (Mas, 2014). Perundangan menyebut terdapat unsur yang diterapkan pada keadaan tertentu yang dalam implementasinya bisa menjadi sarana pemberatan pidana untuk pelaku kejahatan, yaitu jika melakukan perbuatan jahat pada dana-dana ditujukan pada penanganan sosial, krisis ekonomi dan moneter serta kejahatan korupsi.

Berdasarkan uraian di atas, penelitian ini dilakukan untuk menguraikan pengaturan tentang tindak pida korupsi dana hibah dan mendeskripsikan sanksi pidana terhadap pelaku tindak pidana korupsi.

\section{METODE PENELITIAN}

Pendekatan penelitian yang digunankan untuk mendesain penelitian ini adalah pendekatan hukum normatif. Penelitian ini dilakukan dengan berdasarkan pada perundang-undangan yang berlaku. Data skunder yang diperoleh dari Undang-Undang, hasil penelitian, dan koran merupakan sumber data penelitian ini. Studi kepustakaan merupakan metode pengumpulan data yang digunakan dalam studi ini. Metode kualitatif merupakan metode analisis data yang digunakan pada tulisan ini, dan hasil analisis data disajikan secara deskriptif.

\section{HASIL DANPEMBAHASAN}

\section{Pengaturan tentang Tindak Pidana Korupsi Dana Hibah}

Korupsi dijalankan untuk membuat kaya pribadinya atau orang lain hal itu adalah bertentangan dengan hukum (Wiyono, 2005). Definisi korupsi secara yuridis ataupun dilihat dari segi umum sebenarnya adalah sama. Pembedanya adalah kalau dari yuridis arahnya ke unsur delik sudah terformulasi pada perundangan, disisi lain korupsi dalam pandangan umum diartikan penyuapan, wewenang disalahgunakan dan tidak sesuai hukum, hanya untuk untuk dirinya, menjualbelikan pengaruh, dll, sifatnya tidak baik (Kristiana, 2016).

Di Indonesia, langkah-langkah untuk membentuk hukum positif untuk menangani masalah korupsi telah dilakukan selama beberapa periode sejarah dan melalui beberapa periode perubahan undang-undang. Dalam KUHP sebenarnya ada ketentuan yang mengancam tindak pidana orang yang melakukan pelanggaran, khususnya pelanggaran yang dilakukan oleh pejabat terkait dengan korupsi. Kurang efektifnya ketentuan KUHP mengantisipasi dan memecahkan masalah korupsi, sehingga dibentuk perundangan baru agar bisa meminimalisasinya. Harapan yang diinginkan adalah supaya perundangan baru tersebut mampu mengisi dan menjadikan KUHP sempurna.

Dana hibah dikatakan sebagai barang, finansial atau pelayanan yang diberikan pemerintah satu ke lainnya, usaha daerah, publik dan organisasi masyarakat bersifat tidak berkelanjutan dan bersifat membatasi dan dimaksudkan untuk mendukung pelaksanaan urusan pemerintahan. Dana subsidi disalahgunakan termasuk tindak pidana korupsi jika unsur memperkaya diri sendiri atau orang lain, dipenuhi, bahwa manfaat bantuan sosial sudah dipakai untuk kepentingan sendiri atau lainnya dan menyimpang dari maksud semula dana bantuan yang ditunjuk.

Subsidi bantuan sosial oleh negara adalah agenda pemerintah termasuk pada APBN atau APBD yang tercantum pada Permendagri No. 32 setiap subsidi untuk bantuan sosial pemerintah dalam bentuk uang atau benda tidak berbeda dengan hukum yang ditetapkan. Jika manfaat bantuan sosial disalahgunakan dan tidak mematuhi aturan, bantuan sosial disalahgunakan telah memenuhi unsur berbahaya bagi situasi finansial atau ekonomi negara disebabkan tidak sejalan dengan konsep yang disediakan oleh APBD, untuk membangun serta menyejahterakan rakyat.

Penyimpangan manfaat bantuan sosial pun sudah memenuhi unsur penyelewenangan wewenang di dalamnya, karena menurut perundangan yang berlaku dana subsidi dikucurkan ke komunitas atau grup masyarakat khusus. Penggunaan bantuan sosial juga diatur dalam Pasal 24, ayat (6) Peraturan 
Menteri Dalam Negeri Nomor 32 tahun 2011; rehabilitasi sosial, perlindungan sosial, pemberdayaan sosial, jaminan sosial, pengentasan kemiskinan dan bantuan bencana.

Dalam KUHP ada fakta bahwa ada ketentuan yang mengancam pelanggaran orang yang melakukan kejahatan, khususnya kejahatan terkait korupsi. Ketidakefektifan aturan pada KUHP untuk menanggulangi korupsi, Itulah sebabnya sebuah undang-undang telah dirancang untuk memberantas masalah korupsi dengan harapan orang-orang dan untuk memperbaiki kekurangan dalam hukum pidana.

\section{Sanksi Pidana terhadap Pelaku Tindak Pidana Korupsi Dana Hibah}

Sanksi pidana ialah tipe sanksi yang diberikan pada orang yang melanggar dan merugikan kepentingan banyak orang. Intinya sanksi pidana adalah jaminan bagi pemulihan tingkah laku orang yang berbuat jahat. Kerap sanksi diberikan sebagai ancaman terhadap manusia menjadi tidak bebas.

Pidana adalah penghukuman atau kenestapaan secara sengaja diberikan kepada pelaku kejahatan dan terpenuhinya syarat tertentu (Andrisman, 2009), sedangkan Saleh mengemukakan pendapat, pidana adalah respon terhadap delik, dan berupa hukuman dengan sengaja oleh Negara pada pembuat delik (Chaerudin, 2013).

Sanksi pidana adalah sanksi yang lebih keras daripada pengenaan sanksi dalam hukum perdata dan administrasi. Pendekatan yang dikembangkan adalah langkah pencegahan dan meminimalisir kejahatan bersarana hukum pidana dengan pelanggaran yang dijatuhi sanksi pidana.

Berdasarkan Putusan Nomor: 32/Pid.Sus.TPK/2016/PN.Dps, bahwa tersangka atas nama yang berinisial IWB melakukan pelanggaran hukum. Dari kasus tindak pidana korupsi dana hibah Studi Putusan Nomor 32/Pid.Sus.TPK/2016/PN.Dps terdakwa yang berinisial IWB melakukan perbuatan tersebut dengan cara tersangka atas nama yang berinisial IWB setelah menerima uang dana hibah tersebut dari bendesa adat sesuai dengan Kwitansi penyerahan dana aci masing-masing sebesar Rp. 100.000.000,- tanggal 17 Februari 2014 dan Rp. 250.000.000,- pada tanggal 28 Maret 2014 untuk dimasukan kedalam kas Desa Adat dan dicatatkan dalam buku kas. Namun oleh tersangka uang kas tersebut tidak dicatatkan dalam buku kas sebagai penerimaan dan menyatakan kepada bendesa adat bahwa uang tersebut dipergunakan untuk melakukan pembayaran masing-masing sebesar Rp. 100.000.000,- (seratus juta rupiah) pada tanggal 17 Februari 2014 untuk pembayaran pelunasan pembelian Gong dan sebesar Rp. 250.000.000,- (dua ratus lima piluh juta rupiah) pada tanggal 28 Maret 2014 untuk pembayaran terima gedung SMP Taman Sastra lokasi di Jl. Bukti Permai Jimbaran, namun dari pemeriksaan dan dari hasil audit dari BPKP pada Buku Kas Desa diketahui bahwa uang dana hibah tersebut tidak pernah dicatatkan sebagai penerima Desa Adat Jimbaran dan pelunasan pembayaran Gong dan pembayaran pembangunan Gedung SMP Taman Sastra menggunakan uang kas desa adat sehingga terhadap uang hibah tersebut tidak dapat dipertanggungjawabkan oleh Bendahara Desa Adat.

Tersangka sebagai bendahara II di Desa Adat Jimbaran telah memenuhi unsur-unsur sesuai dengan pasal 3 bersamaan dengan pasal 18 Undang-Undang Republik Indonesia nomor 20 tahun 2001 dan sesuai dengan keterangan saksi sebanyak 25 (dua puluh lima) orang dan dikumpulkan bukti, pertimbangan oleh Majelis Hakim memutuskan tersangka yang IWB awalnya dinyatakan salah membuat tindakan korupsi hibah Rp350 juta (tiga ratus lima puluh juta rupiah), kemudian dihukum penjara 1 tahun kurungan dan ganti rugi Rp. 50.000.000, jika tidak dibayarkan, menggantinya melalui hukuman penjara 1 bulan dan uang negara akan dibayar dalam jumlah Rp, 350.000 .000 (tiga ratus lima puluh juta Rupiah).

\section{SIMPULAN DAN SARAN \\ 1. Simpulan}

Berdasarkan hasil penelitian ini, maka dapat disimpulkan beberapa hal, yaitu: pertama, tindak pidana korupsi dana hibah diatur dalam Pasal 1 butir (14) Peraturan Dalam Negeri (Permendagri) Nomor 39 Tahun 2012 akibatnya adalah koruptor diberi hukuman pidana penjara, dan kedua, pemberiansanksipadaterdakwaakandijatuhihukumanbilamanadakwaan sudah terbukti secara sah dan meyakinkan sesuai norma.

\section{Saran}

Pemerintah sebagai aparatur negara harus secara hati-hati memantau pemberian hibah dan harus membangun sistem transparansi dan kredibilitas bagi pemerintah daerah dan memberikan penerima 
dengan rincian yang jelas dan wajib tentang penggunaan dan akuntabilitas mereka, sehingga dana hibah tidak selalu menonjol dan benar memiliki manfaat nyata untuk mengembangkan kapasitas masyarakat, meningkatkan partisipasi dalam pembangunan dan menciptakan kesejahteraan bagi masyarakat. Pentingnya aturan wajib sehubungan dengan publikasi perencanaan, penganggaran dan distribusi laporan hibah, sehingga lembaga pengawas, publik dan pihak terkait dapat dengan mudah mendapatkan informasi sebagai bentuk pengawasan sehingga jawaban atas pengeluaran tidak hanya datang dari aspek laporan administrasi, tetapi juga berkaitan dengan prosesnya, penerbitan dan manfaatnya dapat dinikmati oleh masyarakat, sehingga tidak ada penyimpangan dalam penyediaan dana subsidi.

Penegakan hukum oleh pemerintah Indonesia membutuhkan lebih banyak sanksi dan peraturan tentang pemberian hibah, sehingga dana hibah dibelanjakan sesuai dengan tujuannya dan dengan jelas mendefinisikan perumusan pengeluaran anggaran hibah untuk kapasitas keuangan daerah dan klasifikasi pemenuhan fungsi pengeluaran wajib dan pengeluaran untuk fitur yang dipilih sebagai prioritas untuk pembangunan daerah sehingga dana subsidi riil yang mendukung pembangunan dan kesejahteraan daerah menjadi efektif, efisien dan sukses. Kriteria yang efektif diukur berdasarkan parameter yang dapat mencapai kepentingan maksimum masyarakat dari berbagai kelompok dan lapisan sosial.

\section{DAFTAR PUSTAKA}

Andrisman, T. (2009). Asas-Asas dan Dasar Aturan Hukum Pidana Indonesia. Bandar Lampung: Unila. Arifin, D. N., \& Yusnita, N. (2017). Analisis Proses Perencanaan Penganggaran Hibah dan Bantuan Sosial yang Bersumber dari Anggaran Pendapatan dan Belanja Daerah (Studi Pada Dinas Pendapatan Pengelolaan Keuangan Dan Aset Daerah Kabupaten Morowali). E Journal Katalogis, 5(12), 86-98.

Chaerudin. (2013). Pelajaran Hukum Pidana I. Jakarta: Raja Grafindo Persada.

Cohan, A. S. (2000). Corruption: Causes, Consequences and Control. Asia-Pacific Development Journal, 7(2), 461-462. https://doi.org/10.2307/2617599

Djaja, E. (2010). Peradilan Tindak Pidana Korupsi. Jakarta: Sinar Grafika.

Djelantik, S. (2008). Korupsi, Kemiskinan dan Masalah di Negara Berkembang. Jurnal Administrasi Publik Unpar, 5(1). Retrieved from https://media.neliti.com/media/publications/73661-IDkorupsi-kemiskinan-dan-masalah-di-negara.pdf

Hamzah, A. (2005). Perbandingan Korupsi di Berbagai Negara. Jakarta: Sinar Grafika.

Kristiana, Y. (2016). Pemberantasan Tindak Pidana Korupsi Perspektif Hukum Progresif. Jakarta.

Mas, M. (2014). Pengantar Ilmu Hukum (1st ed.). Bogor: Ghalia Indonesia.

Poveda, A. C., Carvajal, J. E. M., \& Pulido, N. R. (2019). Relations between economic development, violence and corruption: A nonparametric approach with DEA and data panel. Heliyon, 5(4), e01496. https://doi.org/10.1016/j.heliyon.2019.e01496

Pradana, H. A. (2020). Tindak Pidana Korupsi Dalam Pemberian Dana Hibah. Jurist-Diction, 3(1), 153. https://doi.org/10.20473/jd.v3i1.17629

Riawati, N. (2016). Potensi Korupsi dalam Kebijakan Publik Studi Kasus Korupsi Program Penanganan Sosial Ekonomi Masyarakat di Provinsi Jawa Timur. Jurnal Ilmu Sosial Dan Ilmu Politik, 19(2), 154. https://doi.org/10.22146/jsp.10851

Setiyono, B. (2017). Memahami Korupsi di Daerah Pasca Desentralisasi: Belajar Dari Empat Studi Kasus. Politika, 8(1), 27-62. https://doi.org/10.14710/politika.8.1.2017.27-62

Widiastuti, T. W. (2009). Korupsi dan Upaya Pemberantasannya. Jurnal Wacana Hukum, 8(2), $107-$ 118. Retrieved from https://media.neliti.com/media/publications/23536-ID-korupsi-dan-upayapemberantasannya.pdf

Wiyono, R. (2005). Pembahasan Undang-Undang Pemberantasan Tindak Pidana Korupsi (II). Jakarta: Sinar Grafika.

Zulkifli, Fitriati, \& Ferdi. (2018). Penerapan Unsur Tindak Pidana Korupsi Pada Pelaksanaan Program Kemitraan dan Bina Lingkungan. Unes Law Review, 1(2). Retrieved from https://media.neliti.com/media/publications/73661-ID-korupsi-kemiskinan-dan-masalah-dinegara.pdf 